\title{
Growth promotants in feeding pigs and poultry. III. Alternatives to antibiotic growth promotants
}

\author{
Sigvard Thomke*, Klas Elwinger \\ Department of Animal Nutrition and Management, Sweden Univ Agric Science, P.O. Box 7024, \\ Ultuna, S-750 07 Uppsala, Sweden
}

(Received 2 December 1997; accepted 27 May 1998)

\begin{abstract}
On the basis of improving effects of antibiotic growth promoters in pigs and poultry being mediated through their regulating influence on the gastro-intestinal flora, a number of alternative additives and feeding strategies are reviewed. Nutrient absorption is facilitated by dietary incorporation of suitable enzyme preparations, thereby decreasing intestinal disorders and upsets. As a result, performance is improved, particularly in juveniles. Microbial preparations (probiotics) have also been claimed as alternatives to growth promoters of antibiotic type. However, the efficacy of probiotic preparations seems to be less consistent than the use of antibiotic-type preparations. Dietary acidifiers have also been proposed. Furthermore, the choice of ingredients and their technological treatment should also be considered as a strategy to tailor diets according to the specific capacity and requirements of the animal group. Recently, feed induced formation of lectins or peptides has been proposed as an efficient method to prevent diarrhoea in pigs by their action on the central regulating system of intestinal fluid secretion. Finally, the environmental and management conditions of the production systems are of very great importance to secure a safe development of animals. The need for more research in the area of alternatives to antibiotic-type antibiotics is emphasised. (다이 Elsevier / Inra)
\end{abstract}

growth promoter / antibiotic / pig / poultry / alternatives to antibiotics

Résumé - Les promoteurs de croissance dans l'alimentation des porcs et des volailles. III. Alternatives à l'emploi des antibiotiques. Après un bref rappel du processus de digestion chez les espèces monogastriques, l'article décrit les divers additifs qui peuvent être proposés dans l'alimentation des porcs et des volailles comme alternatives à l'emploi des antibiotiques, agents promoteurs de croissance. L'incorporation d'enzymes peut améliorer, dans des situations définies, les capacités digestives des animaux, notamment des plus jeunes. Les enzymes permettent une meilleure utilisation des nutriments en rendant possible leur absorption au niveau du tube digestif. Elles limiteraient par leur action, l'incidence et la sévérité des déséquilibres intestinaux. Les probiotiques (préparations microbiennes) peuvent aussi affecter avantageusement les performances animales. Cependant, leur efficacité demeure variable et dépend de nombreux facteurs liés à l'état physiologique,

* Correspondence and reprints

Tel: (46) 186710 00; fax: (46) 186729 95; e-mail: klas.elwinger@huv.sluse 
nutritionnel et sanitaire des animaux ainsi que de facteurs liés à la viabilité et à la stabilité génétique des microorganismes qui entrent dans leur composition. Les acidifiants alimentaires ont également été proposés comme alternative. Le choix des ingrédients et de leur traitement technologique pourrait aussi être envisagé comme stratégie pour améliorer les régimes en fonction des capacités et besoins des animaux. La formation de lectines ou de peptides induite par l'alimentation préviendrait ainsi les risques de diarrhées chez le pore en agissant sur le système nerveux central de régulation de la sécrétion intestinale. Les conditions environnementales et de gestion des systèmes de production sont également d'une importance majeure pour assurer un développement adéquat des animaux. (C) Elsevier/Inra)

promoteur de croissance / antibiotique / porc / volaille / additifs

\section{INTRODUCTION}

As a background to this section, the digestive systems and events in pigs and poultry are briefly described. The gut flora has fascinated scientists for more than 100 years and the importance of its stability for the healthy development of a species was obvious before the introduction of the terms probiosis/probiotic. The nutrient environment is another area that has an impact on gastrointestinal events. Since the supplementation of enzymatic preparations became economically feasible, such supplements might be tools to improve animal performance and avoid health disorders. A deep knowledge of interactions between the gastrointestinal milieu and central mechanisms regulating gut health opens new ways of controlling animal health by balancing the dietary supply of lectins.

\subsection{Digestive system of monogastric animal species}

The digestion of food and feeds involves a series of processes along the gastrointestinal tract, by which dietary components are broken down into smaller particles to facilitate solubilisation in order to make absorption possible. This is accomplished by a combination of mechanical and enzymatical processes along the tract. Microorganisms are more or less, and according to animal species, involved in digestive activity. The function of the mouth is chiefly to disintegrate the ingested feed by mastication, to lubricate it for the process of swallowing and simultaneously to contribute to a regulation of the $\mathrm{pH}$ of the ingested feed by the saliva produced in order to control the microbial activity in the stomach. In the mouth, saliva and saliva mucins selectively inhibit the binding of food lectins to the teeth and mouth cavity, thereby minimizing agglutination and adherence of bacteria to the teeth [97]. Poultry have no teeth, they swallow their feed whole. Any grinding of the feed occurs by grit in the gizzard. The crop is a semi-batch lactic acid fermentation storage compartment situated cranially to the gizzard and is specific to birds, as also is the proventriculus localized between the crop and the gizzard. This is an enzymeproducing organ, which corresponds to the gastric enzyme and $\mathrm{HCl}$ production in the stomach of for example the pig and also of man. In the proventriculus and the gizzard of birds, the $\mathrm{pH}$ is very low [8].

The extent of digestive action in the stomach varies between animal species. The predominant digestive components in the stomach secreted by the gastric mucosa are $\mathrm{HCl}$ and pepsin, which are aimed at hydrolysing protein into polypeptides. In many monogastric species, carbohydrates are fermented into lactic acid and volatile fatty acids by gastric microbial fermentation. The extent of this microbial action varies greatly between species and also reflects feed environment as a microbial substrate. 
As in most other mammals, stomach emptying in the pig is brought about by contractions passing down the pyloric region into the duodenum. Nervous and humoral feedback mechanisms, largely in the duodenal region, regulate the ingesta passage. Factors that trigger gastric emptying are the volume of its content and dietary composition. The rate of ingesta passage through the small intestine is very fast and it slows down successively along the small tract. Regularly it takes $2.5 \mathrm{~h}$ for a given particle to pass the small intestine. At this high speed of digesta passage it would be difficult for microorganisms to colonize this region. The epithelial cell layer is continuously regenerating, therefore microorganisms can colonize the small intestine only if their proliferation rate is faster than the sloughing rate [61].

The small intestine is the primary site for absorption of amino acids, saccharides, lipids, vitamins and minerals. Carbohydrate digestion occurs mainly as a result of enzymes produced by the small intestine. The breakdown products absorbed are glucose, galactose and fructose. Birds lack the capacity to break down lactose as they do not produce lactase. In most mammalian species, lactase production decreases with the development of the animal. As mentioned earlier, part of the protein digestion occurs in the stomach. A further digestion of protein occurs in the small intestine by the action of pancreatic trypsin, chymotrypsin and carboxypeptidases forming peptides and amino acids to be absorbed in the small intestine. Nucleoproteins are digested by intestinal nucleotidases and nucleosidases formed by the small intestine. Lipids are broken down by lipase chiefly formed by the pancreas and are absorbed as fatty acids and glycerol. Of minor importance is the fat absorption as glycerides.

Following solubilisation, minerals and vitamins are predominantly absorbed in the small intestine.

\subsection{Importance of the gut flora}

Bacteria are the most important of the symbiotic organisms breaking down carbohydrates and which predominantly occur in the hind gut of monogastric animal species. This symbiosis, which corresponds to the fermentation processes of cattle, sheep etc., also gives monogastric animals the advantage of breaking-down complex structures, and also to synthesize essential nutrients such as vitamins and amino acids. The environmental conditions in the hindgut are critical for the host animal mainly from two aspects. In order to optimize the conditions, including those for the microorganisms, with respect to an appropriate function of the processes in the hind gut, a certain amount of nutrients and bulk (indigestible organic matter) is needed, which has to be considered in the feeding strategy. Secondly, the feeding strategy has to take into account the enzymatic capacity of the animal, implying avoidance of overloading the digestive system and the abduction (transfer) of unutilized nutrients from the small intestine into the distal part of the gastrointestinal tract, i.e., the caecal and colonic region. An unregulated nutrient flow would create uncontrolled microbial proliferation and overgrowth, causing problems to the host animal, e.g., in horses developing the most common type of colic.

\section{FEED ADDITIVES WITH ENZYMATIC PROPERTIES}

Historically, the feed industry has been reluctant to include barley in broiler diets. The relatively high fibre content associated with the high hull content, predominantly occurring in winter barleys, has earlier been claimed to be one reason. Theoretically, this should pose no substantial problem as chickens as well as pigs compensate for the lowered dietary energy concentration by an increased feed intake. Unfortunately, barley, like oats and rye, may contain soluble, 
non-digestible carbohydrates, such as $\beta$-glucans and arabinoxylans, which create problems in growth performance by their high water-binding capacity, thereby increasing morbidity, mortality and wet litter condition in poultry.

\subsection{Mode of action by enzymatic preparations}

It has been demonstrated in broiler chickens that soluble fibre components decrease feed intake by lowering the rate of feed passage, thus lowering performance results [ 18 , $19,32,34,44,110]$. According to these authors, impaired water retention in the gastrointestinal tract results in sticky droppings, followed by impaired litter condition and decreased hygiene and an increase in mortality. Furthermore, high viscosity cereals lower the rate of starch disappearance from the small intestine [44], affecting the microbial flora in the distal gastrointestinal tract. Another important feature of supplementing enzymes is their capacity of making nutrients available to the animal, which otherwise would not be utilized. Furthermore, the improved utilization of feedingstuffs and lowered excretion of nutrients following enzyme supplementation has implications from the environmental point of view by limiting nutrient discharge. Quantitatively, enzymes attacking carbohydrates (carbohydrases) belong to the most important group of enzymes, compared with proteases and lipases. In his thesis Inborr [53] has summarized the mode of action of carbohydrate degrading enzymes in pig starter diets (figure 1).

\subsection{Impact of cereal bases and enzyme supplementation in pig diets}

Nutrient digestibility and performance responses in pigs by enzyme preparations have been reviewed (table I) in order to examine their quantitative effects and to exem- plify their potential. With respect to the great number of published data, this table represents only a limited part of the work performed in this area. Even though there is a vast body of information, details on the mode of action are still lacking. Obviously, more research is needed to develop more potent enzymes and to find efficient combinations of enzyme preparations suitable for individual and compounded feeding stuffs. Moreover, methods should be developed in order to protect the potential of these preparations until they are expected to act.

By supplementing high viscosity barley with $\beta$-glucanase, Thomke et al. [1 1111$]$ improved piglet organic matter digestibility and animal growth rate. Newman et al. [88] tested bacterial diastase and reported an improved nutrient digestibility of hulless barley as well as growth performance in growing pigs. Administering viscous polysacccharides to the diet of pigs was shown to increase pancreatic exocrine secretion and rate of gastrointestinal feed passage [16]. Graham et al. [41] observed improved ileal and total tract digestibility of barley by supplementing $\beta$-glucanase/pentosanase when testing on growing pigs. By supplementing a rye-based diet with pentosanase, Thacker et al. [108] were able to report a tendency towards an improved average daily growth rate in growing pigs (table I). These authors concluded that soluble pentosans did not appear to pose as large a problem for pigs as they do for poultry.

The effect of enzyme treatment of the cereal part in a piglet diet and the dietary supplementation of enzymes on growth performance and incidence of diarrhoea was assessed by Inborr and Ogle [57] (table I). Post weaning daily weight gains were slightly higher for the diet based on cereals pretreated with carbohydrate degrading enzymes as compared with a negative control. Bedford et al. [11] observed that $\beta$-glucanase supplementation of a pig starter diet based on hulless barley significantly improved the apparent protein digestibility 


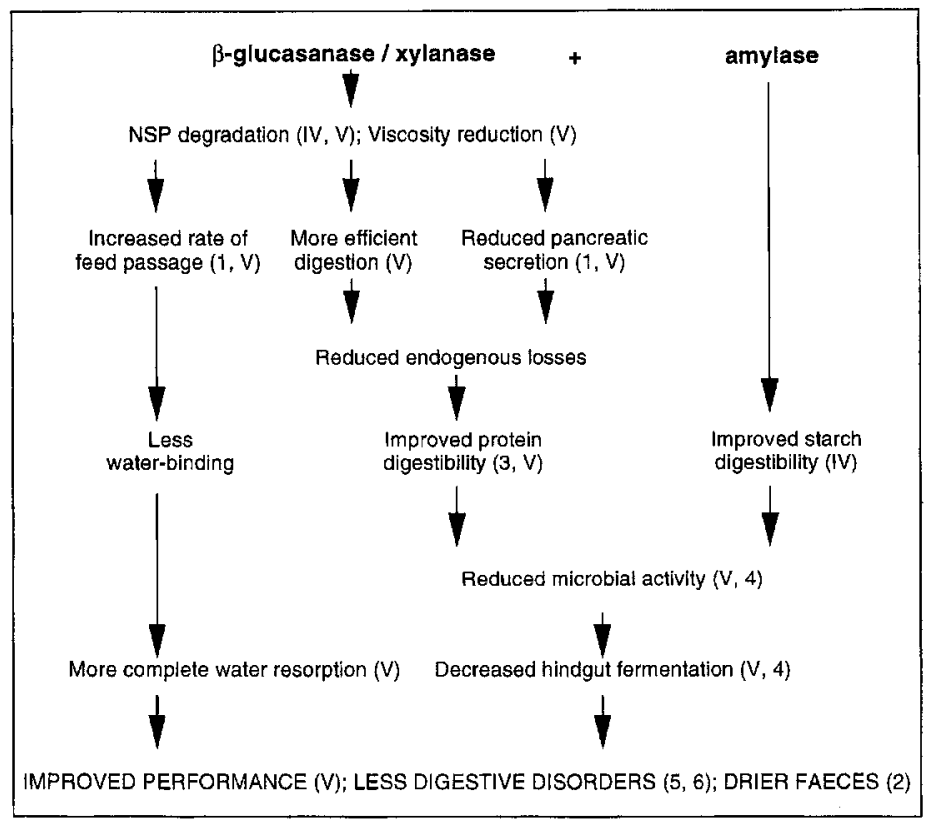

Figure 1. Mode of action of carbohydrate degrading enzymes in pig starter diets based on barley and wheat: 1, [16]; 2, [53]; 3, [11]; 4, (Kamphuis, 1987; cited in [53]); 5, [57]; 6, [14] (for the references given here see Inborr [53]); I, [55]; II, [56]; III, [53]; IV, [58]; V, [54].

over the entire small intestine and tended to reduce ingesta viscosity. A slight, but significant $(P<0.05)$, decrease was observed in the incidence of diarrhoea in the experimental group compared with the control. In one of two piglet performance tests, Böhme [14] demonstrated a significant $(P<0.05)$ improvement in performance. In both experiments, the incidence and severity of diarrhoea was reduced, indicating that the enzyme supplementation had a beneficial effect attributable to a stabilizing effect of the enzymes included in the piglet diets.

For monitoring the effects of enzyme supplementation the responses in organic matter and energy digestibility as well as in feed efficiency may be useful measures. Growth rate seems to be inferior since this trait may be affected by feed intake [110]. When quantitatively evaluating the information compiled on pigs in table $I$, it seems likely that piglet feed efficiency-responses are superior to those observed in growingfinishing pigs, which seems plausible with respect to the development occurring with age in the gastrointestinal tract. In accordance with what may be expected, enzyme responses at the precaecal level to dietary enzyme supplementation are superior to those observed for the total tract. For piglets, an average feed efficiency-response by enzymes of approximately $4 \%$ may be calculated, whereas for growing-finishing pigs this value averaged about $2 \%$ for feed efficiency as well as for energy digestibility (GE).

\subsection{Impact of cereal bases and enzyme supplementation in poultry diets}

The stage of ripeness of barley at harvest has earlier been demonstrated to affect performance of broiler chickens [110]. This condition was demonstrated to be overcome 


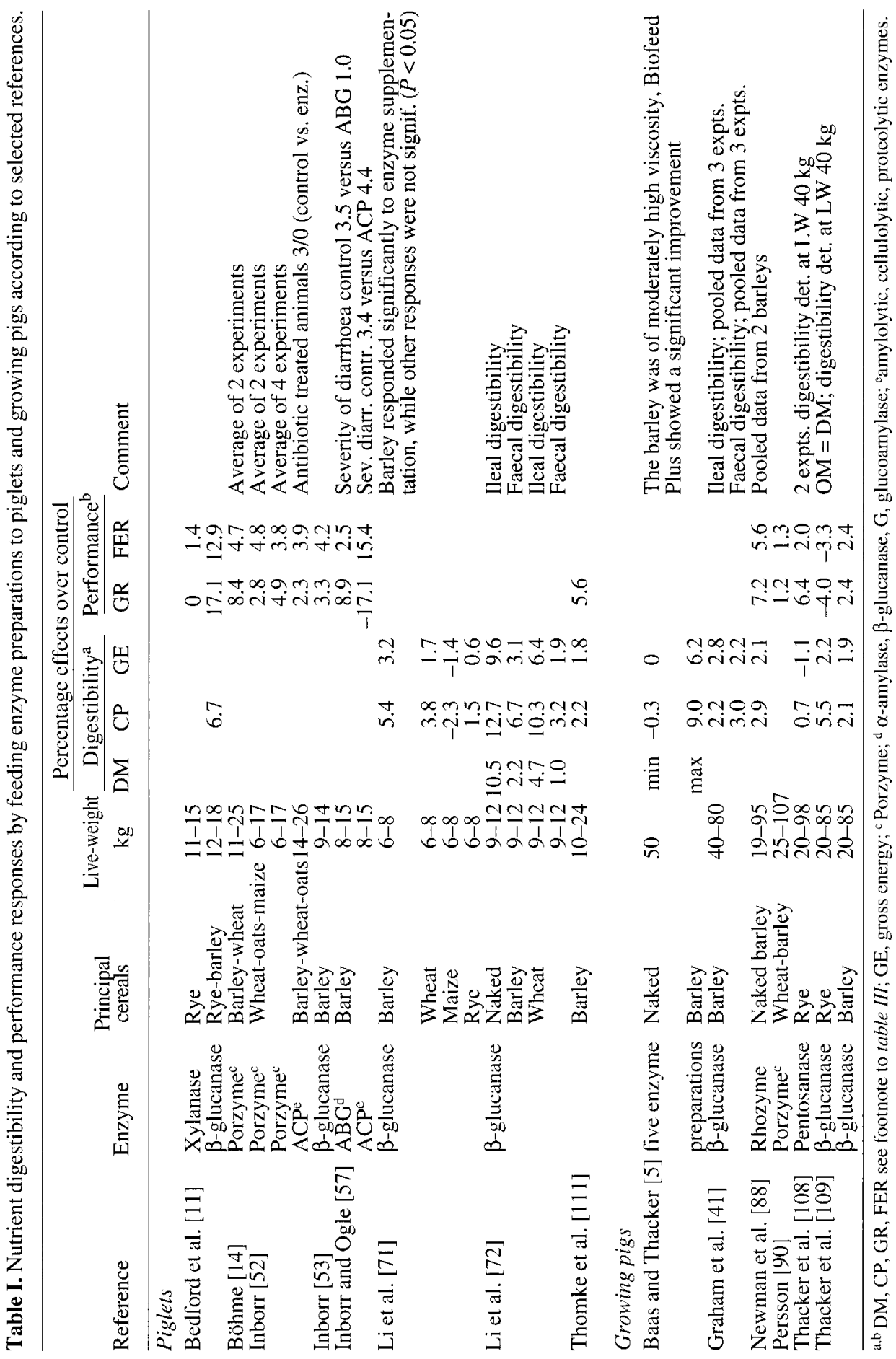


by supplementation of barley diets with $\beta$-glucanase $[45,46]$. The improved performance results with barley harvested at the stage of full ripeness versus early ripeness were demonstrated to be related to the extract viscosity of barley as a measure for the content of $\beta$-glucans.

In comparing wheat, rye and three different cultivars of triticale as cereal bases in broiler chicken diets, Pettersson and Åman [94] noticed remarkable differences in bird performance, with the poorest results on rye and the best on wheat, with triticale in between (table II). On all cereal bases, this investigation also included a treatment with the supplementation of an enzyme preparation with pentosanase, $\beta$-glucanase and some other enzyme activities. For the wheat-based diet the enzyme effect was limited and statistically non-significant, whereas for all other cereal bases the overall enzyme supplementation effect on performance and feed intake was significant $(P<0.001)$.

Recently, by dietary supplementation of glucanase, Choct [17] demonstrated an improvement of AME (apparent metaboli- zable energy) in wheat by $24 \%$ and commented that it is now generally conceded that the occurrence of low-ME in wheat is due to an increased level of NSP (non-starch polysaccarides), and of arabinoxylan in particular. This author also quotes Australian work according to which $25 \%$ of wheat samples had an AME-value < $13 \mathrm{MJ}$ per $\mathrm{kg}$. Furthermore, by investigating the variation in ME-values in UK wheat samples, McNabb [81] reported a difference of $2 \mathrm{MJ}$ per $\mathrm{kg}$ DM and suspects that the content of NSP causes the variation and that this, in turn, is related to the content of arabinoxylans in wheat. Therefore, this author expects positive responses by supplementing wheatbased poultry diets with $\beta$-glucanase and xylanase.

By supplementing a basal broiler chicken diet with NSP causing high viscosity in the gastrointestinal tract, Choct et al. [18] tested the effect of an enzyme (glucanase) preparation on bird performance, intestinal ingesta viscosity, fatty acid concentration and microbial activity and dietary AME. NSP inclusion lowered growth performance and feed efficiency of the birds and dietary

Table II. The effect on feed intake, live weight, feed conversion of broiler chickens at 21 days of age fed diets based on wheat, rye and triticale without (-) and with (+) enzyme supplementation [94].

\begin{tabular}{|c|c|c|c|c|}
\hline & & $\begin{array}{l}\text { Live weight } \\
\text { (g) }\end{array}$ & $\begin{array}{l}\text { Feed intake } \\
\quad(\mathrm{g})\end{array}$ & $\begin{array}{c}\mathrm{kg} \text { feed } / \mathrm{kg} \text { weight } \\
\text { gain }\end{array}$ \\
\hline Wheat & $\begin{array}{l}- \\
+\end{array}$ & $\begin{array}{l}582^{\mathrm{cde}} \\
602^{\mathrm{e}}\end{array}$ & $\begin{array}{l}900^{\mathrm{b}} \\
920^{\mathrm{h}}\end{array}$ & $\begin{array}{l}1.55^{\mathrm{c}} \\
1.53^{\mathrm{c}}\end{array}$ \\
\hline Rye & $\begin{array}{l}- \\
+\end{array}$ & $\begin{array}{l}364^{a} \\
528^{\mathrm{b}}\end{array}$ & $\begin{array}{l}723^{a} \\
904^{h}\end{array}$ & $\begin{array}{l}1.99^{\mathrm{a}} \\
1.72^{\mathrm{b}}\end{array}$ \\
\hline $\begin{array}{r}\text { Triticale } \\
\text { Laska }\end{array}$ & $\overline{-}$ & $\begin{array}{l}560^{\mathrm{d}} \\
596^{\mathrm{cc}}\end{array}$ & $\begin{array}{l}876^{\mathrm{hc}} \\
899^{\mathrm{b}}\end{array}$ & $\begin{array}{l}1.56^{\mathrm{c}} \\
1.51^{\mathrm{c}}\end{array}$ \\
\hline WW & $\begin{array}{l}- \\
+\end{array}$ & $\begin{array}{l}565^{\mathrm{d}} \\
595^{\mathrm{ec}}\end{array}$ & $\begin{array}{l}886^{\mathrm{bc}} \\
913^{\mathrm{b}}\end{array}$ & $\begin{array}{l}1.57^{\mathrm{c}} \\
1.54^{\mathrm{c}}\end{array}$ \\
\hline SV & $\begin{array}{l}- \\
+\end{array}$ & $\begin{array}{l}497^{+} \\
572^{\text {ed }}\end{array}$ & $\begin{array}{l}843^{\mathrm{c}} \\
898^{\mathrm{b}}\end{array}$ & $\begin{array}{l}1.70^{\mathrm{h}} \\
1.57^{\mathrm{c}}\end{array}$ \\
\hline
\end{tabular}

a. b. c. d. e, f Means within columns that do not share a common superscript differ $(P<0.05)$. 
AME. This investigation corroborates earlier work and demonstrates that increased fermentation occurs in the small intestine when large amounts of viscous NSP are included in the diet, which is detrimental to the performance and well-being of poultry. These results are in line with views put foreward by Bedford and Morgan [10] indicating that enzyme additives mainly act by reducing digesta viscosity.

Elwinger and Teglöf [35] demonstrated in one investigation that the incidence of necrotic enteritis in broiler chickens could be lowered by the dietary inclusion of an enzyme preparation, whereas in a more recent report by Elwinger et al. [30], caecal Clostridium perfringens counts were not affected. As a side-effect, an improved litter condition with better bird hygiene and lowered ammonia emission can be expected [31].

References on nutrient digestibility and performance responses in poultry by dietary enzyme supplementation have also been compiled (table III). There is a tremendous variation in responses, which demonstrates the complexity of finding efficient combinations of enzymes under the differing circumstances in nutrient supply. An example of this may be the Polish work by Alloui et al. [3], in which six lupin varieties were supplemented with different enzyme preparations, giving an average enzyme response in AME of $10 \%$. NDF digestibility of lupins was significantly improved between 2 and $21 \%$. Surprisingly, growth responses in broiler chickens fed diets including the same batches of lupins to enzyme supplementation could not be observed. Similarly, Australian workers [4] were unable to reveal any enzyme related responses on performance in broiler chickens fed diets incorporated with lupins. Of interest beyond cereals, is the work by Slominski [104] with rapeseed meal as the principal feedstuff. Adult birds responded to enzyme supplementation with an increase in the AME by $9.7 \%$ (table III)

An important issue in future diet formulation is the inclusion of more specific enzymes, which is likely to become more common, not only in order to solubilize cereal carbohydrtaes, but also NSP (nonstarch polysaccharides) of grain legumes like lupins (with $36 \%$ NSP of DM), peas (35\%), soyabeans ( $30 \%$ ) etc. According to Choct [17] an important portion of the potential energy of these types of feedstuffs has to be broken down by microbial fermentation in monogastric animal species, thereby causing a drop in the efficiency of energy turnover, but also risks for upsets in the digestive tract.

A successful use of proteases has been reported by Pettersson [93] in diets for early weaned piglets.

By evaluating the experimentation in table III on cereals as principal feedstuffs for broiler chickens and their responses to enzyme supplementation on feed efficiency one arrives at an estimated average improvement by $4 \%$, which agrees fairly well with the extensive compilation by Kronseder [66].

In a broiler chicken experiment, Elwinger and Teglöf [35] tested barley-based diets without and with the inclusion of an enzyme preparation and without and with the supplementation of virginiamycin. The outcome demonstrated a significantly improved 35-day performance as a result of both enzyme and virginiamycin supplementation (table IV). The effect of enzyme supplementation was greater when testing without the inclusion of virginiamycin than with. By the supplementation with enzyme mortality, incidence of sticky droppings and litter condition were greatly improved. By including virginiamycin in the diet the effect of the enzyme preparation was not significant for growth rate and very limited for feed efficiency. Nevertheless, there was an effect on water intake and litter condition. This experiment demonstrates that part of the beneficial effects achieved by virginiamycin could be obtained by the dietary enzyme inclusion. The interaction observed between enzyme and virginiamycin sup- 


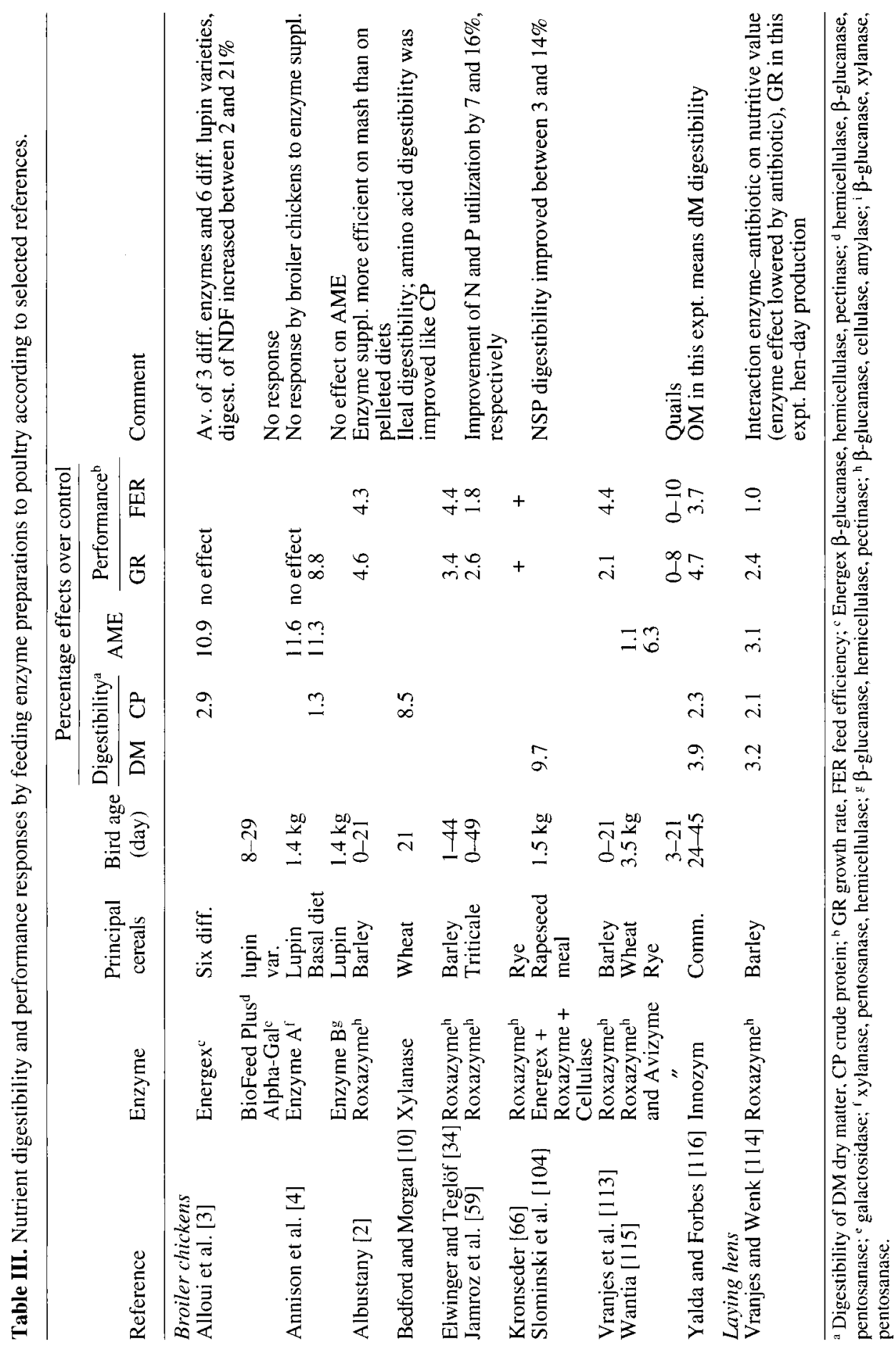


Table IV. 35-day results of performance of broiler chickens fed barley-based diet supplemented with virginiamycin (VIM) and/or enzyme preparation (E), according to Elwinger and Teglöf [34].

\begin{tabular}{|c|c|c|c|c|c|c|c|c|c|}
\hline & \multicolumn{3}{|c|}{$\begin{array}{l}\text { Without virginiamycin } \\
\text { Enzyme }^{b} \text { added (ppm) }\end{array}$} & \multicolumn{3}{|c|}{$\begin{array}{l}\text { With virginiamycin } \\
\text { Enzyme added (ppm) }\end{array}$} & \multicolumn{3}{|c|}{ Effect of ${ }^{a}$} \\
\hline & 0 & 100 & 200 & 0 & 100 & 200 & VIM & $\mathrm{E}$ & $\mathrm{E}^{*} \mathrm{VIM}$ \\
\hline Live weight (g) & 1453 & 1533 & 1523 & 1525 & 1546 & 1552 & $* * *$ & $* * *$ & $(*)$ \\
\hline kg feed/kg (WG) & 1.86 & 1.79 & 1.79 & 1.79 & 1.78 & 1.77 & $* * *$ & $* * *$ & $* * *$ \\
\hline Mortality (\%) & 7.9 & 3.5 & 2.7 & 1.9 & 2.6 & 1.4 & $*$ & $*$ & $*$ \\
\hline Sticky droppings (\%) & 35 & 4 & 1 & 9 & 2 & 1 & $* * *$ & $* * *$ & $* * *$ \\
\hline Litter DM (\%) & 53 & 57 & 59 & 50 & 60 & 61 & NS & $* * *$ & NS \\
\hline
\end{tabular}

a NS, non-significant; WG, weight gain; $* P<0.05$; ** $P<0.01$; *** $P<0.001$.

${ }^{\mathrm{b}}$ Roxazyme G.

$c$ at 7 days.

plementation is corroborated by the results of Kronseder [66].

In a wheat-soybean oil diet, Miles et al. [83] tested the effect of enzyme and virginiamycin supplementation singly or synergistically on broiler chickens. Best performance results were obtained for the enzyme supplemented singly or in combination with virginiamycin. The enzyme supplementation also lowered the viscosity of small intestine ingesta. There were no health problems observed in this experiment, probably as a result of using wheat as the cereal basis, in contrast to the barley used in the investigation by Elwinger and Teglöf [34].

Vranjes and Wenk [114] studied the influence of an enzyme complex combined without and with antibiotic (flavophospholipol) supplementation on nutrient utilization and performance of laying hens fed a diet based on winter barley $(40 \%)$. The enzyme significantly increased dietary AME, organic matter and NDF digestibility. The antibiotic had no influence on energy value or nutrient utilization. There were no significant treatment effects observed on egg production.

The effects of combining enzyme supplementation (combination of $\beta$-glucanase and pentosanase) with salinomycin on growing pigs fed barley- or rye-based diets has been investigated by Thacker et al. [109]. Neither enzyme nor salinomycin, alone or in combination, significantly improved the growth rate or feed efficiency of pigs fed barley or rye. The digestibility of crude protein was significantly improved by salinomycin. The lack of, or lower response of, dietary enzyme supplementation on pig performance demonstrates a species-related difference compared with birds, i.e., poultry, and particularly birds $<3$ weeks of age respond more effectively to enzyme supplementation.

\subsection{Lactoperoxidase in calves}

The above-mentioned enzymes are added in order to improve nutrient availability in the gastrointestinal tract. In contrast to these enzymes, naturally-occurring enzymes with antimicrobial effects may be addressed as alternatives to traditional growth promotants. The lactoperoxidase system (LPS) is intimately associated with the antibacterial activity of bovine milk [99]. By supplementing LPS to calves in the early stage of development, the animals being sensitive to bacterial and viral infections and often suffering from diarrhoea, this author demonstrated significantly improved weight gains of calves as well as lowered incidence of diarrhoea. 


\subsection{Environmental implications of enzyme supplementation}

It has been pointed out in an earlier section that the effects of enzyme supplementation are generally to enforce the animal's own nutrient degrading capacity and/or to complement it. This means that a greater share of the nutrients supplied in the feed than in the unsupplemented diet is solubilized in the gastrointestinal tract and hence made available for absorption by the animal or to be attacked by microorganisms along the tract. The animals respond to the improved nutrient supply by increased growth rate as well as by improved feed efficiency. Simultaneously, the higher rate of nutrient absorption leads to a lowered output of these with animal voidings and is, therefore, also an advantage from an external environment point of view.

In terms of improved digestibility and feed efficiency a fair estimate for the improvement by enzyme supplementation for young pigs and poultry according to the literature reviewed above would be approximately $3-4 \%$. Calculating with an average digestibility of organic matter in cerealbased diets for these animal species of $80 \%$, one arrives at a decrease in animal nutrient voidings by $15-20 \%$.

\section{PROBIOTICS}

\subsection{Definition of a probiotic preparation}

Originally the term probiotic was introduced for a substance secreted by a microorganism to stimulate the growth of another organism. It meant the exact opposite of the term antibiotic. Later, the term has been widened to include organisms and substances that contribute to improved animal health and intestinal microbial balance. Fuller [37] recently redefined probiotic as live microbial feed supplement that beneficially affects the host animal by improving its intestinal microbial balance. Probiotics may contain one or several strains of microor- ganisms and may be presented to the animal in the form of solitary microbial additives or mixed with different substances and are distributed to the animal orally as powders (in water or in feed) or directly as tablets, granules or pastes. The probiotics can be given as viable organisms in wet form, frozen or freeze-dried. However, the viability of preparations varies greatly depending on the type of organism, its preparation and treatment post-propagation, including feed processing and storage.

The beneficial claims made for probiotic supplementation are numerous and include improvement of growth rate of farm animals, improved utilization of the food, improved milk production by dairy cows and improved egg production. Probiotics may also directly or indirectly improve animal health [37].

\subsection{Gastric and small intestine microbial flora}

The main areas of microbial interference in the bird are the crop, the first major site for colonization following the ingestion of microorganisms, and the caeca, as the primary colonization site for a number of pathogens including Salmonella and Campylobacter. Corresponding sections of the gastrointestinal tract in the pig are the stomach, small intestine and to some extent the hind gut region.

The foregut (stomach and small intestine) of the pig is colonized by a relatively rich microbial flora and the stomach ingesta of a healthy pig contains $10^{7}-10^{9}$ bacterial organisms per $\mathrm{g}$. As the relatively low $\mathrm{pH}$ of the stomach only has a limited destructive effect on its microbial population, bacterial numbers found in the small intestine are generally also high. The microbial flora occurring in the foregut is dominated by lactic acid forming bacteria (LAB) Lactobacillus and Streptococcus spp. These organisms are found in the digesta and attached to the epithelium [61]. 


\subsection{Hindgut microbial flora}

There is a difference in the composition of the microbial flora in the caecum and the colon with Gram-negative dominating the former and Gram-positive dominating the latter. There are several circumstances that enable the LAB microflora to dominate within the digestive tract of the pig. The lactic acid fermentation in the stomach is facilitated by a relatively high $\mathrm{pH}$ and by the inoculation with the specific flora of the ingesta in the pars oesophagea of the stomach. Both the lactic acid formed in the stomach by microbial fermentation and the low $\mathrm{pH}$ in the pylorus as a result of the $\mathrm{HCl}$-production in the stomach have been claimed to reduce the number of bacteria passing into the small intestine. Similarly, in the bird, microorganisms that survive the low $\mathrm{pH}$ in the gizzard generally multiply in the small intestine. In young animals, the digestive ecosystem is often less stable than in older animals, thus in the former class of animals opportunistic pathogens more easily invade the digestive tract than in older animals.

The study by Robinson et al. (1981 cited by Stewart and Chesson [106]) revealed that about $80 \%$ of the cultivable caecal bacteria in the healthy pig were Gram-negative. The relative proportions of the predominant species are shown in figure 2.

\subsection{Mode of probiotic action}

As modes of action of probiotics it has been suggested that the indigenous microflora and the introduced probiotic out-compete the pathogen as discussed in terms of colonization resistance (Hentges (1992) cited by Conway [20]). The fatty acid metabolites, predominantly lactic and acetic acid, produced by the LAB are inhibitory to the growth of pathogens. However, the efficacy of these components in controlling pathogens has been questioned [61] since the acids are inhibitory only in the undissociated state, which occurs at low $\mathrm{pH}$. The $\mathrm{pH}$ in the small intestine of pigs and birds seems to be too high to allow the fatty acids to be inhibitory at their full potential in vivo.

Some microbial probiotic strains have been shown to produce inhibitory components other than the short chain fatty acids. This type of larger proteinaceous compounds are referred to as bacteriocins (Kleenhammer (1988) cited by Conway [20]). However, questions are raised if these components can be produced and are functioning in vivo. There are numerous gut bacteria which have been shown to have inhibitory effects on $E$. coli. Similarly, numerous Lactobacilli spp. isolated from the gut of pigs have been demonstrated to produce high molecular mass components, which

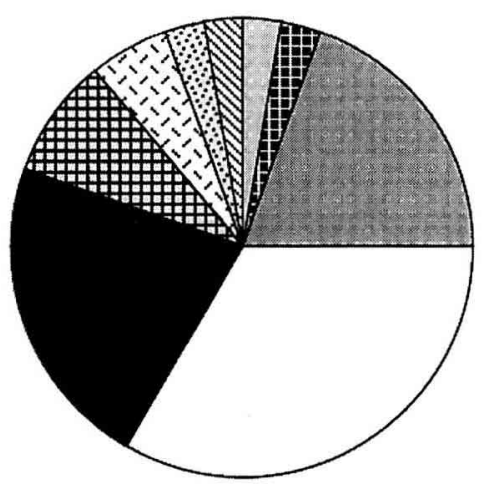

Bacteroides ruminicola Selenomonas ruminiantium $\boxplus$ Lactobacillus acidophilius Butyrivibrio fibrisolvens Peptostrococcus productus Bacteroides uniformis Eubacterium aerofaciens F Lactobacillus fermentum Others

Figure 2. Relative frequencies of bacterial species in caecal contents of pigs (according to Robinson et al. (1981) cited by Stewart and Chesson [106]). 
exert inhibitory effects on a range of Gramnegative and Gram-positive pathogens. A problem is, however, that strains frequently lose their capacity to produce these components [20]. Furthermore, it has been demonstrated that piglet ileal digesta contents contain heat labile components, which have growth-inhibiting effects on $E$. coli. A prerequisite of intestinal development of pathogens is their adhesion to the gut wall. It has been shown in vitro that probiotic strains may produce metabolites that inhibit the adhesion of the pathogens (Blomberg et al. (1992) cited by Conway [20]), but this has not yet been demonstrated in vivo.

\subsection{Problems in evaluating probiotics}

The type of diet and the amount of nutrients are important for the development of the intestinal microflora. Lactobacilli, having a complex nutrient requirement, seem thus to be more sensitive to the gut nutrient milieu compared with, e.g., $E$. coli [61]. Starvation survival capacity of Lactobacilli spp. of digestive origin in the total absence of nutrients seems to be excellent. It is hypothesised that the starvation survival mechanisms of Lactobacilli have a very low threshold for nutrients, beyond which growth is initiated [61]. The probiotics can be supplied to the animal orally, distributed in water or in feed.

The efficacy of probiotics has recently been reviewed for birds [8] and pigs [20,61, $106,112]$. The microbiology of the gut and the role of probiotics have recently been further reviewed by Maxwell and Stewart [80].

According to Jonsson and Conway [61] assessments of the efficacy of probiotics in vivo include studies of:

- influence on the microflora in the digestive tract, including pathogenic bacteria;

- influence on the digestive tract, its function and morphology;

- performance and health of animals;

- various effects where animals are used as models for humans, e.g., anticholesterolaemic properties, stimulation of the immune system and anticarcinogenic activity.

The type of probiotic preparation and the time of its introduction and the persistence would be of importance for effects induced on the host animal. The active component of a probiotic concept could be either a preformed active antagonistic substance or a viable microorganism culture. The former type seems to be the easiest concept with respect to control dosage and monitoring responses. The efficacy of the latter type of probiotic preparations is much more complicated since many factors are involved in establishing the microflora to colonize, e.g., the viability and genetic stability of the organisms of the preparation as well as their effects on the gastrointestinal ecosystem.

\subsection{Efficacy of probiotics in pigs}

As pointed out by Pollman [95] and again recently by Jonsson and Conway [61] when reviewing the literature on pigs, a great number of microorganisms have been tested as probiotics (table V), part of which have been isolated from the indigenous intestinal microflora, whereas other organisms represent other origins. Species normally found in the intestine of the pig are L. acidofilus, L. fermentum, L. reuteri, Enterococcum faecium and E. faecalis. Lactobacilli are more sensitive to pelleting and storage than, e.g., Streptococci and the spore-forming Bacillus spp. There are important differences between strains regarding their characteristics and ability to colonize.

According to the literature compiled by Jonsson and Conway [61], it seems likely that a number of probiotics in many instances affect the gastrointestinal microbial flora, particularly in cases where the indigenous digestive tract flora has been disturbed. Not always would this balancing by dietary probiotics have an improving effect 
on the health and performance of the host animal. In cases when this stabilizing can not be achieved, detrimental effects on health and performance could be expected.

The efficacy of administrating probiotics is dependent on a number of circumstances, e.g., the physiological or health status of the animal, environmental factors such as feed regime and microbial load. Improving effects are more often observed in neonatal animals and in pre- and post-weaning piglets. In some herds long-term diarrhoea has successfully been treated with Streptococci. According to the authors quoted recently, these circumstances point to the fact that the digestive microflora may be favourably influenced by the dietary inclusion of LAB, particularly in young animals. Furthermore, it seems more likely to expect probiotic response in situations of negative stress of some kind. However, one has to consider that the indigenous digestive floræ

Table V. Microorganisms used as probiotics for pigs according to Jonsson and Conway [61].

\begin{tabular}{|c|c|c|}
\hline Organism & Form & Number of references ${ }^{a}$ \\
\hline \multirow[t]{5}{*}{ Lacobacillus acidophilus } & Cultured milk & 5 \\
\hline & Frozen culture & 3 \\
\hline & Freeze-dried & 1 \\
\hline & Dried & 1 \\
\hline & FP & 1 \\
\hline L.lactis & Frozen & 1 \\
\hline L. reuteri & Cultured milk & 1 \\
\hline \multirow[t]{3}{*}{ Lactobacillus spp. } & Cultured milk & 3 \\
\hline & Dried & 1 \\
\hline & FP & 2 \\
\hline Enterococcus faecalis & Spray-dried & 1 \\
\hline E. faecium & Freeze-dried & 12 \\
\hline Bacillus licheniformis & Spores & 1 \\
\hline B. subtilis & Spores & 1 \\
\hline B. subtilis var. toyoi & Spores + FP & 4 \\
\hline Bifidobacterium bifidum & Dried & 1 \\
\hline B. pseudolongum & Dried & 1 \\
\hline B. thermophilus & Dried & 1 \\
\hline Clostridium butyricum & Dried & 1 \\
\hline Saccharomyces spp. & Dried & 1 \\
\hline Yeasts & Dried & 1 \\
\hline \multicolumn{3}{|l|}{ Mixed organisms: } \\
\hline Pediococcus acidilactici & Dried & 1 \\
\hline \multicolumn{3}{|l|}{ L. plantarum } \\
\hline \multicolumn{3}{|l|}{ L. casei } \\
\hline \multicolumn{3}{|l|}{ L. fermentum } \\
\hline \multicolumn{3}{|l|}{ L. brevis } \\
\hline L. delbrueckii subsp. bulgaricus & FP & 1 \\
\hline \multicolumn{3}{|l|}{ L. casei } \\
\hline \multicolumn{3}{|l|}{$\begin{array}{l}\text { Streptococcus salivarius subsp. } \\
\text { thermophilus }\end{array}$} \\
\hline L. plantarum & Dried & 1 \\
\hline \multicolumn{3}{|l|}{ L. acidophilus } \\
\hline Yoghurt organisms & Yoghurt & 1 \\
\hline Lactic culture & Freeze-dried \pm FP & 1 \\
\hline
\end{tabular}

a See Jonsson and Conway [61]; FP, fermentation product. 
are very potent in preventing other microorganisms from colonizing permanently.

In piglets weaned at the age of 2 days Ratcliffe et al. [98] investigated the effect of yoghurt and milk fermented with a porcine intestinal strain of $L$. reuteri on performance and gastrointestinal flora. Yoghurt feeding resulted in slightly inferior piglet weight gain and significantly poorer feed efficiency. It also depressed coliform counts, whereas Lactobacillus counts along the tract increased. $L$. reuteri gave results similar to those obtained with yoghurt, but the effects did not persist after withdrawal. The authors concluded that the decrease in coliform counts was a result of the low $\mathrm{pH}$ produced by the lactic acid production in all milk diets fed. In commenting these results, one has to consider the bactericidal effect of lactate on intestinal microbial flora in addition to the $\mathrm{pH}$ effect.

In order to obtain more consistent effects on these two types of probiotic preparations much more basic knowledge is required in the area of our understanding of the interactions in the digestive microbial ecosystem. As an example, Jonsson and Conway [61] outline in figure 3 the area of interactions between animal, diet, microorganisms, digestion and the immune response as being in need of better understanding.
A summarizing statement by Jonsson and Conway [61] regarding the efficacy of probiotics in pigs may be cited: "From studies to date it is feasible to postulate that probiotic preparations could contain microbes with the capacity to improve piglet health by direct inhibitory effects on the enteropathogenic bacteria. The in vitro and in vivo demonstration and characterization of inhibitory components will ensure functional preparations. Identifications of adhesions which mediate in vivo colonization will allow better predictions if probiotic preparations have the capacity to colonize the digestive tract. Probiotic strains with demonstrable direct effects may also function indirectly by stabilizing the digestive microflora at times when the ecosystem is stressed. This latter vital role is restricted until the complex interactions within the digestive tract are better understood."

\subsection{Specific types of phages in pigs}

During the past decade bacteriophages have again been advocated as a novel method to control pathogens. By treatment and prophylaxis, virulent phages have successfully been demonstrated to control $E$. coli infections in mice and enterotoxigenic $E$. coli diarrhoea in pigs, calves and

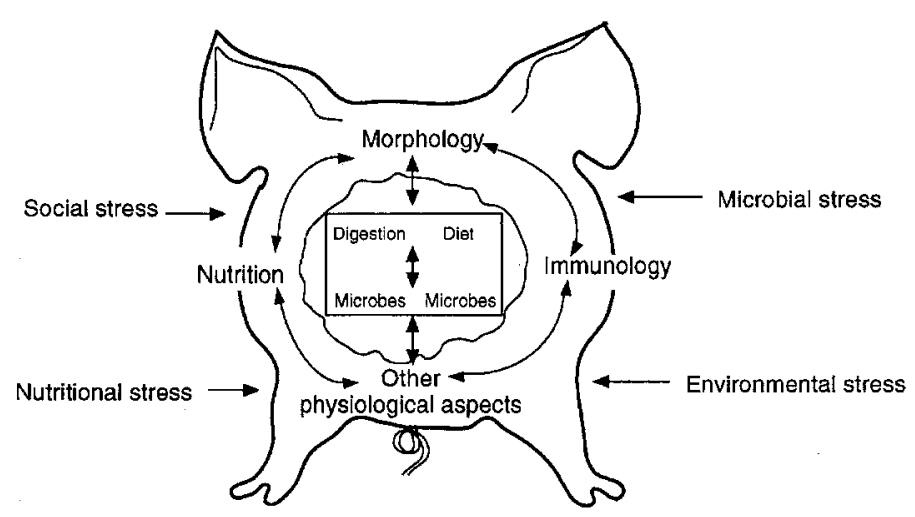

Figure 3. To further understand how probiotics exert their effect, studies on the total ecosystem of the pig in its specific environment will be needed (according to [61]). 
lambs (Smith and Huggins 1982, 1983, cited by Barrow [8]).

\subsection{Efficacy of probiotics in poultry}

In evaluating the great number of reports on the efficacy of probiotic organisms and substances in poultry, Barrow [8] points out a number of difficulties for a critical appraisal. The vast majority of results on the efficacy of probiotics in poultry is reported as abstracts with essential information lacking, e.g., on the identity of strains used and on experimental design (e.g., [73]). In many cases, non-avian Lactobacillus strains are used which are known not to colonize. The implantation in the gastrointestinal tract of the strains used is rarely assessed. The microbiological results in nutrition-oriented papers are often poorly interpreted. A further comment is that in a number of reports in which performance and health could be improved by probiotics, the general conditions seem to have been poor and non-representative with respect to production level and morbidity. Moreover, Barrow [8] in his review considers that some of the interpretations of the results are obviously over optimistic and arise mainly from a naive and uncritical acceptance of the data or speculations of previous workers.

Probiotic preparations evaluated on broiler chickens in Sweden have demonstrated only inconclusive results [29].

Nguyen et al. [89] reported improving growth performance and feed conversion at 42 days of age in broiler chickens fed diets either unsupplemented (A) or supplemented with (B) flavomycin; (C) toyocerin (spores of Bacillus toyoi); (D) paciflor (spores of a Bacillus sp. stored at the Institut Pasteur) or (E), a combination of $B+D$. For treatment groups $\mathrm{B}-\mathrm{E}$ the 42 -day average weight gains of the birds differed significantly $(P<0.01)$ from the unsupplemented control A $(P<0.01)$ by $+1.8 ;+2.0 ;+2.5$ and $+2.8 \%$, respectively. Corresponding values for feed conversion $(\mathrm{kg}$ feed/weight gain, $P<0.05$ ) were $-2.3,-0.7,-2.3$ and $-2.7 \%$. Similar improving results have been reported by Kahrs [62] for toyocerin in growing pigs, however, with the greatest promoting effect in the first growing phase compared with the final phase.

Recently, Mohan et al. [85] reported on the effects of administering a probiotic mixture (L. acidophilus, L. casei, Bifidabacterium bifidum, Aspergillus oryzae and Torulopsis in descending order of concentration) for broiler chickens with the inclusion of 0 , 75,100 and $125 \mathrm{mg} / \mathrm{kg}$ diet. Mean weights at the termination ( 8 weeks) of the experiment were 1204, 1272, 1268 and $1210 \mathrm{~g}$. At ages of 4, 5 and 6 weeks, mean weights differed significantly between control and probiotic treatments. Feed conversion ratio varied between 2.31 and $2.26(\mathrm{~kg}$ feed $/ \mathrm{kg}$ WG). The dietary AME was not affected by probiotic supplementation. However, in evaluating this experiment, the relatively limited growth performance in relation to modern commercial strains with 8 weekLW of more than $2500 \mathrm{~g}$ should be considered.

According to Dunham et al. [22], laboratory and large-scale field tests have demonstrated significant benefits from the treatment of young birds with host specific strains of $L$. reuteri, particularly when the animals are subjected to environmental and/or pathogenic stressors. Treated flocks consistently exhibited fewer deaths, superior growth rates and improved feed efficiency. These authors state that $L$. reuteri treatment confers these benefits through $\mathrm{CE}$ (competitive exclusion) mechanism and by modulating the newborn's immune response. In comparison with control birds these authors observed: longer ileal villi and deeper crypts, a response associated with enhanced T-cell function; suppressed PHA-induced (phytohemagglutenin) epidermal DTH (delayed type hypersensitivity) reaction and, furthermore, increased production of serum anti-salmonella IgM antibodies. 
An example of another type of probiotic in a wider sense is the development of live Salmonella vaccines for chickens. Linde et al. [74] developed a method for optimally attenuating Salmonella vaccines by using two metabolic drift mutants deficient in the production of essential enzymes.

According to the overview by Mead [82], there are a number of commercial preparations available that successfully have been used in the prophylaxis of Clostridium and Salmonella infections in poultry. Recently, Abu-Ruwaida et al. [1] confirmed the potential of this method against Salmonella. Also Swedish experimental results when using the probiotic Broilact ${ }^{\circledR}$ have been promising, with a significantly lowered mortality in one of the experiments and lowered caecal counts of C. perfringens [33].

The prophylactic treatment against salmonellosis is based on the principle of early establishment of an adult intestinal microflora in the young bird by supplying a suspension or anaerobic cultures of intestinal material to provide necessary organisms in the gastrointestinal tract thereby competitively excluding pathogen organisms. Young birds given this peroral treatment rapidly develop protection against a subsequent $\mathrm{Sal}$ monella challenge. Although there are theoretical risks in using undefined treatment products to combat Salmonella infections in poultry, these products, which are widely spread, are appropriately controlled. However, criteria on which to select pure cultures of microorganisms for protective purpose are lacking at present and will remain so until more is known about factors influencing Salmonella colonization at the cellular level and the protective mechanism(s) involved [82]. According to this author, future preparations will need to be selected on a sound scientific basis and be more protective and more stable than those developed so far.

The complexity of Salmonella colonisation is exemplified by the effects of the supplementation of the antimicrobial avopar- cin in Salmonella typhimurium infected chickens. Although individual intestinal microorganisms have been demonstrated to be susceptible to this drug in vitro [7], different groups of researchers have reported increased and avoparcin-induced Salmonella counts at the caecal level or in the droppings [7, 51, 70]. These findings contradict those of Gustafson et al. [43], one explanation possibly being differences in the technique of transfer of Salmonella organisms, or interaction with other feed additives acting antimicrobially. In cases of natural infection of the birds, Linton et al. [75] were unable to observe any influence of avoparcin or monensin on Salmonella shedding. On providing broiler chickens a diet supplemented with a combination of avoparcin and monensin, Holmberg et al. [50] 1 and 2 weeks after challenge noticed higher caecal counts and Salmonella infected livers than straight avoparcin supplementation.

In summarising the literature on probiotics in poultry, Barrow [8] points to the considerable importance of the microbial flora in the avian gastrointestinal tract for performance and animal health. Any imbalance in the gut flora could lead to the colonisation of pathogens or to a microbial flora that might impair performance. There are some probiotics (particularly Lactobacilli spp.) that have proven beneficial effects on performance, especially in young birds and when stressed by adverse environmental conditions. Elimination of wet droppings and occluded vents were also observed in some experiments as a result of dietary $\mathrm{Lac}$ tobacilli administration. However, there are also reports on uniformly negative results of administrating Lactobacillus products on egg production. Supplementation with Streptococcus spp. has often been reported to give adverse effects on performance of growing birds. By administering $L$. acidophilus it seems possible to lower enteric pathogens (E. coli, Salmonella) but not to control them completely. 


\subsection{Specific types of phages in poultry}

Phages lytic for Salmonella typhimurium have been isolated from poultry feed, excreta and sewage [8]. According to this author, such an approach would be interesting to consider for Campylobacter and growthdepressing organisms. Recently, Poppe et al. [96] observed $97 \%$ of Salmonella strains isolated from a great number of laying hen and broiler herds in Canada to be susceptible to the lytic effect of polyvalent bacteriophages.

\section{EFFECTS OF VARYING FEED INGREDIENTS}

\subsection{Fermentable carbohydrates}

For the survival and the adhesion of the microbial, including probiotic, flora at the gut cell level the necessity of a suitable nutrient environment in the gastrointestinal tract has been pointed out by several authors (e.g., $[8,61,82,106]$ ). By reviewing the literature on dietary administration of fermentable carbohydrates as to manipulate the normal intestinal flora, Barrow [8] pointed out several reports in which the supply (via the feed or via the drinking water) of e.g., lactose or mannose decreased caecal pathogen counts (e.g., Salmonella typhimurium) by stimulating the lactose fermenting flora inhibiting the growth of pathogenic bacteria and reducing the severity of infection with Eimeria.

In an experiment with broiler chickens, Stanley et al. [105] tested the dietary admixture of $0.2 \%$ lactose on bird growth rate and caecal total bacteria coliform counts. In comparison with the control diet without incorporation, the admixture of lactose improved (however, statistically non-significant) the final live weight at 3 weeks of age by $6 \%$. The caecal coliform counts were drastically decreased from $5.98 \log _{10}$ in birds fed the control diet to $3.8 \log _{10}$ by the admixture of lactose.

\subsection{Dietary acidifiers}

In the search for feed additives with gut $\mathrm{pH}$ stabilizing effects, organic as well as inorganic acids have been proposed and used since the 1950s. Citric acid has widely been used in piglet diets, so also orto-phosphoric acid. Even $\mathrm{HCl}$ acid has been tested [101]. Recently, Höhler and Pallauf [47] demonstrated an improved $\mathrm{Zn}$-absorption by the inclusion of $1 \%$ citric acid in piglet diet. Broz and Schulze [13] noticed an improved organic matter digestibility by including $0.5-2 \%$ citric acid in early weaned piglet diets.

The inclusion of formic acid (FA, at 0 , $0.6,1.2,1.8$ and $2.4 \%$ ) and $\mathrm{Ca}-$ or Na-formiate into piglet diets has been investigated quite extensively by Kirchgessner and his group. As reported by Roth et al. [100] stomach $\mathrm{pH}$ and stomach DM content was not affected, whereas $\mathrm{pH}$ in the small intestine, caecum and colon increased in proportion to the dietary FA level. Digesta DM content increased distally with the inclusion of FA. At the two highest FA levels the concentration of digesta VFA (volatile fatty acids) decreased. By including $1.25 \% \mathrm{FA}$ or $1.8 \%$ Ca-formiate into piglet diets Bacteroidaceae spp. and E. coli counts along the small intestine decreased, whereas simultaneous inclusion of $\mathrm{NaHCO}_{3}$ increased the microbial counts [65]. As the main active mechanism of organic acid supplementation on gut flora microbiology, Eidelsburger et al. [27] point out the anions of the organic acids. These authors tested also $\mathrm{HCl}(1.4 \%$ admixture), but found it to have a depressive effect on piglet feed intake and performance. $\mathrm{NH}_{3}$-formation in the stomach, small intestine and colon was significantly limited by 0.6 and $1.2 \% \mathrm{FA} \mathrm{[28]} \mathrm{and} \mathrm{HCl}$ or fumaric acid inclusion [101]. In addition to these effects, Eckel et al. [24] reported a lowering effect on caecal digesta concentrations of cadaverin, putrescin and spermidin. Similarly, Mosenthin et al. [87] observed a significantly lowered caecal digesta cadaverin concentration when admixing $2 \%$ propio- 
nic acid in a growing pig diet. These authors also observed a significantly improved ileal digestibility of some essential amino acids as a result of propionic acid admixture. FA levels $>1.2 \%$ have been demonstrated by Grassmann et al. [42] to have adverse metabolic effects by changing blood serum and liver aminotransferase activity as well as increasing blood serum urea concentration.

In a 41-day feeding experiment with piglets (28-day-old at the start) fed diets admixed with either 0 (control), $0.6,1.2$ or $1.8 \%$ FA, Eckel et al. [25] improved piglet feed intake (in \% over the control) by 14 , 13 and $4 \%$, respectively, average daily weight gain by 22,22 and $5 \%$, respectively, and feed efficiency by 6,8 and $1 \%$, respectively. The incidence of diarrhoea was significantly decreased by FA [23]. The highest level of $2.4 \%$ FA inclusion exerted negative effects on performance.

\subsection{Protein sources}

In the Swedish pig and poultry industries the dietary levels of protein have steadily decreased during the $1980 \mathrm{~s}$ in order to minimize intestinal disorders, but also to decrease the external environmental load via animal production. This has been possible since several crystalline amino acids are available at competitive price levels. There have been indications that animal protein sources are more prone to give rise to digestive tract problems than non-animal protein sources in both pig [38] and poultry [29] production. Part of these negative responses to dietary protein level seems to be related to gastrointestinal allergic reaction by the animals to certain protein structures [84]. In some of the experiments with broiler chickens, the exclusion of animal protein feedstuffs resulted in a lowered incidence of necrotic enteritis, whereas this was not consistently observed in subsequent experiments [29]. These authors occasionally found higher mortality following inclusion of fishmeal than inclusion of meat and bone meal in broiler diets.
With respect to the dietary cereal supply, Kaldhusdal [63] pointed out that a high level of maize in broiler chicken diets gave protection against necrotic enteritis, whereas barley and wheat were identified as risk factors.

Rapeseed meal had earlier been claimed to lower bird gut health $[91,92]$. When studying the caecal $C$. perfringens counts and the incidence of necrotic enteritis, Elwinger et al. [29] were unable to observe any negative effects. However, in this investigation all diets were supplemented with a coccidiostat having antibacterial effects as well.

\subsection{Unmilled wheat}

The development of the bird gizzard is influenced by the dietary physical structure, implying that also digestive enzyme secretion could be affected, thereby triggering development of the gastrointestinal flora. Part of the dietary cereals may, therefore, be supplied unmilled without affecting broiler chicken performance [35]. No differences in bird health were observed. However, bird water intake was significantly lowered by supplying $20 \%$ wheat mixed unmilled with the crumbled pellets, resulting in an improved litter condition, which might imply a safer and more stable hygienic state for the birds. To-day, the whole wheat concept in broiler chicken diets is commonly accepted in Northern Europe [64]. In Canada, Bennett et al. [12] arrived at a similar conclusion that pelleting all the wheat in broiler chicken rations is unnecessary, because bird performance is unaffected by feeding up to $30 \%$ whole grain in the finisher diet.

\subsection{Fibre and lectins}

As mentioned earlier, soluble fibre types (e.g., $\beta$-glucans, arabinoxylans) affect gut function and bird health. Elwinger et al. [29] attempted to evaluate the supplementation of 
particulate fibres (oat hulls and potato fibre products) on gut health of broiler chickens. However, the birds in this experiment suffered from an outbreak of necrotic enteritis and therefore had to be treated with antibiotics. No differences between fibre supplementation on the counts of $C$. perfringens could be observed.

The incidence of post-weaning diarrhoea in pigs has been demonstrated to be related to the dietary content of fibrous components [6]. This has been confirmed in Swedish experiments by Göransson et al. [39]. A $30 \%$ decrease in the incidence of post-weaning diarrhoea was observed as a result of the inclusion of plantago polysaccharides or beet pulp fibre. However, this might be, at least to some extent, a cosmetic effect.

There is an interrelationship between certain naturally occurring or added feed ingredients such as lectins and/or glucoconjugates (usually of plant origin) and gastrointestinal health. These constituents exert their action through competition with the bacterial adhesions or by changing the expression of surface composition for bacterial adhesion, thereby reducing the number of harmful bacteria to a minimum and promoting the proliferation of potentially useful strains. As a result of their specificity, other lectins may favour the attachment of harmful organisms [97]. Certain carbohydrates may interfere and change the surface receptors of the small intestinal brush border. Lectins with the same specificities as bacteria may prevent the attachment and proliferation of appropriate species. The formation of feed-induced lectins by dietary inclusion of certain feed ingredients (sugars, sugar alcohols and amino acids) and their potential in preventing post weaning diarrhoea has been demonstrated by Lönnroth and Lange [76]. Recently, the effects of using oligosaccharides as feed additives have been reviewed by Monsan and Paul [86].

The intestinal fluid secretion is regulated by an anti-secretory factor (ASF, recently the term AF has been used; Göransson, per- sonal communication), peptides which are synthesized in the central nervous system and accumulated in the anterior part of the pituitary gland [60] and which inhibits pathological secretion induced by enterotoxins [67]. AF seems to be of importance in the defence against diarrhoeal diseases [40, $67,69]$. In pigs a very minute amount of AF (only 1 picomole) causes a substantial reduction in enterotoxin-induced intestinal secretion, i.e., induced by verotoxin and $E$. coli heat labile toxin [69]. The AF is passively transferred via sow's milk to the piglet and is present in nursing piglet blood irrespective of a challenge [103]. Soon after weaning, the AF-blood level decreases, but increases again following weaning. Piglets suffering from diarrhoea have lower blood plasma AF-concentrations than healthy littermates [77]. Similarly, the viscosity of droppings of broiler chicken at slaughter after transportation was found to be related to the blood plasma AF-concentration [68].

The efficacy of using AF-inducing diets has been demonstrated in large commercial units [40]. AF-induction via drinking water is an alternative, as demonstrated in a split litter experiment with significantly increased AF plasma-concentrations (table VI; [39]). These authors explain the lower daily weight gains of the control group of piglets in the first week post-weaning by postulating subclinical intestinal disorder and point to the relationship between performance results in the first week after weaning and plasma AFconcentrations. In rats and broiler chickens, stress has been demonstrated to rapidly decrease blood AF-concentrations [68, 77]. Göransson et al. [39] suggest that weaning is a stressful factor that may cause the sudden drop in blood AF-concentration, leading to increased susceptibility for gastrointestinal disorders.

\subsection{Other feed additives}

Recently, Devegowda [21] reviewed herbal medicines as potential feed additives 
Table VI. AF-plasma concentrations and production performance for piglets weaned at 32 days of age (according to Göransson et al. [39]).

\begin{tabular}{|c|c|c|c|c|}
\hline & \multirow[b]{2}{*}{$\begin{array}{l}\text { Control } \\
\text { (C) }\end{array}$} & \multicolumn{2}{|c|}{ AF diet type } & \multirow{2}{*}{$\begin{array}{c}\text { Diet } \mathrm{C}+\mathrm{AF} \\
\text { in drinking. } \\
\text { water } 5 \mathrm{~d} \text {. } \\
\text { prior to and } \\
5 \mathrm{~d} \text {. post-weaning }\end{array}$} \\
\hline & & $\begin{array}{l}\text { A } \\
\text { through- } \\
\text { out }\end{array}$ & $\begin{array}{c}\text { B } \\
10 \text { d. post-w., } \\
\text { then } C\end{array}$ & \\
\hline No of piglets & 28 & 28 & 28 & 28 \\
\hline \multicolumn{5}{|l|}{ Daily weight gains } \\
\hline $14-32$ days & 274 & 280 & 273 & 260 \\
\hline $32-39$ days & $92^{\mathrm{a}}$ & $155^{\mathrm{b}}$ & $187^{\mathrm{b}}$ & $162^{b}$ \\
\hline $39-63$ days & $504^{a b}$ & $525^{\mathrm{ab}}$ & $542^{a}$ & $498^{b}$ \\
\hline \multicolumn{5}{|l|}{$\begin{array}{l}\text { Daily energy intake } \\
\quad(M J M E)\end{array}$} \\
\hline 32-39 days & $4.5 \mathrm{l}^{\mathrm{a}}$ & $5.38^{b}$ & $5.67^{\mathrm{b}}$ & $4.39^{\mathrm{a}}$ \\
\hline $39-63$ days & 10.1 & 10.7 & 10.4 & 10.1 \\
\hline $\begin{array}{l}\text { Post-weaning diarrhoea } \\
\text { (\% of piglets) }\end{array}$ & 0 & 0 & 0 & 0 \\
\hline $\begin{array}{l}\text { Plasma AF } 5 \text { days post- } \\
\text { weaning (units } / \mathrm{mL} \text { ) }\end{array}$ & 0.12 & 1.32 & 1.20 & 1.20 \\
\hline
\end{tabular}

a.b Means within lines with different superscript letters differ with statistical significance $(P<0.05)$.

with growth-promoting effects in animals. In India 7000 herb species are currently in use as medical preparations for humans. This author reported on some experiments in which minute supplements showed interesting results. However, as with other feed additives, when using herbs beyond the question of their efficacy as promotants, the area of residual levels in foods and longterm effects on resistance have to be evaluated.

Zinc is a biogenic element and is regularly supplemented into compounded feed mixtures for all food-producing animal species at a level of $50-100 \mathrm{ppm}$. The inclusion may vary beyond this level. In Denmark in the mid 80 s it was observed that inclusion of high levels ( $2500 \mathrm{ppm} \mathrm{Zn)} \mathrm{of}$ zink oxide in piglet diets had a preventive and curing effect on $E$. coli diarrhoea [48]. According to this author, E. coli diarrhoea in weaners is no longer a problem for Danish veterinarians. Zinc toxicity in pigs is relati- vely uncommon. Clinical signs of this disorder include growth depression, loss of appetite and gastroenteritis. Swedish results agree with the Danish [49]. However, according to EU regulations levels $>250 \mathrm{ppm} \mathrm{Zn}$ are not permitted.

The growth promoting effects of chromium provided as picolinate has been investigated by Boleman et al. [15]. A lowered growth rate was reported as well as an increased daily carcass fat accretion.

\section{IMPROVEMENT OF ANIMAL ENVIRONMENT}

In the search for methods to improve animal health in modern animal production systems, other environmental factors than nutrient supply and feeding strategy have to be considered. Stocking density, environmental temperature and hygienic stage are of great importance. The type of bedding 
material may affect bird mortality, as has been demonstrated by Elwinger et al. [29] by comparing straw and wood shavings with significantly lowered mortality in the latter alternative. According to these authors, differences in mortality may also occur as a result of water supply system. The mixing of piglets in connection with their transfer to fattening units may lead to severe struggles and decreased feed efficiency [36] and is further exemplified by a negative correlation between the number of received attacks and performance results [78, 102].

\section{GENETIC SELECTION}

A further alternative to decrease the incidence of certain types of diarrhoea in piglets is selection. For the incidence of diarrhoea up to 8 weeks post-birth in a Swedish investigation, Stigson [107] reported a heritability of $0.26 \pm 0.10$. A high boar effect on diarrhoea susceptibility was reported by Göransson [38]. By studying the genetic variation in antibody response to $E$. coli antigens 0149 and $\mathrm{K} 88$ the heritability for the increase in IgG titres during the first week following immunization, Edfors-Lilja [26] arrived at values of 0.29 and 0.45 , respectively. Lundeheim [79] investigated the genetic background of respiratory diseases and arrived at heritability values around 0.2 , and higher values for Yorkshire than for Landrace pigs. This research indicates that some of the common pig diseases may be controlled by means of selection.

\section{CONCLUSION}

Livestock performance and feed efficiency are closely interrelated with the qualitative and quantitative microbial load of the host animal, including load in the alimentary tract and in the animal environment. Appropriate nutrient supply and choice of ingredients and their proper preparation with respect to the animal's diges- tive capacity will minimize nutrient losses and overloading, upsets and intestinal overcrowding by often harmful microbial flora. Under given circumstances, supplementing enzymatic preparations may improve the digestive capacity, particularly in juveniles. Thereby, nutrient utilization in the anterior part of the gastrointestinal tract is improved and the incidence of intestinal perturbation may be limited, which thus may lead to a limitation of occasions when antimicrobial treatment of animals has to be used. The dietary inclusion of enzymes of carbohydrase type leads to a more efficient use of nutrients by poultry and pigs, thus decreasing nutrient output with urine and faeces in the range of $15-20 \%$. Organic acids may have controlling effects on intestinal microbial flora through their specific anion actions on microorganisms.

The probiotic concept is based on either preformed antagonistic agents or on a viable microorganism culture with intestinal adhesive capacity. In selecting microbial strains with probiotic potentials, their genetic stability and intestinal colonizing capacity as well as their stabilizing properties are of main concern. Some probiotic preparations (particularly Lactobacilli spp. and yeast types) have been demonstrated to improve juvenile (piglet as well as chicken) performance and health (e.g., preventing salmonellosis in poultry by competitive exclusion). However, so far the efficacy of probiotics seems to be less consistent than the use of antibiotic promotants. In future control of avian salmonellosis, the potential of bacteriophages has to be investigated further as an alternative to antibiotics.

Another way of achieving withdrawal of antibiotic promotants is to manipulate central mechanisms in order to activate the animal's own defence mechanisms. One example in porcine production is the antisecretory factor, a peptide synthesized in the central nervous system and which is accumulated in the anterior part of the pituitary. This peptide regulates the intestinal 
fluid secretion caused by enterotoxins, thus preventing diarrhoea in pigs.

The withdrawal of antibiotic promotants must also be followed by changes and adaptations in livestock production systems in order to prevent transfer of pathogenic microorganisms and other harmful contagious material both between as well as within herds. In developing future livestock production and housing systems stressful situations for the animals have to be avoided and strict health-care plans have to be applied.

\section{ACKNOWLEDGMENTS}

This review was published in the journal of the Royal Swedish Academy of Agriculture and Forestry 136 (19) (1997) 37-65. Permission to reprint it was kindly granted by the Royal Swedish Academy of Agriculture and Forestry.

\section{REFERENCES}

[1] Abu-Ruwaida A.S., Husseini M., Banat I.M., Salmonella exclusion in broiler chicks by the competitive action of adult gut microflora, Microbios 83 (1995) 59-69.

[2] Albustany Z., The effect of pelleting an enzyme supplemented barley based broiler diet, Anim. Feed Sci. Technol. 58 (1996) 283-288.

[3] Alloui O., Smulikowska S., Chibowska M., Pastuszewska B., The nutritive value of lupin seeds ( $L$. luteus, $L$ angustifolius and $L$ albus) for broiler chickens as affected by variety and enzyme supplementation, J. Anim. Feed Sci. 3 (1994) 215-227.

[4] Annison G., Hughes R.J., Choct M., Effects of enzyme supplementation on the nutritive value of dehulled lupins, Br. Poultry Sci. 37 (1996) 157-172.

[5] Baas T.C., Thacker P.A., Impact of gastric $\mathrm{pH}$ on dietary enzyme activity and survivability in swine fed beta glucanase supplemented diets, Can. J. Anim. Sci. 76 (1996) 245-252.

[6] Ball R.O., Aherne F.X., Effect of diet complexity and feed restriction on the incidence and severity of diarrhoea in early weaned pigs, Can. J. Anim. Sci. 62 (1987) 907-913.

[7] Barrow P.A., Further observations on the effect of diets containing avoparcin on the excretion of salmonellas by experimentally infected chickens, Epidemiol. Infect. 102 (1989) 239-252.
[8] Barrow P.A., Probiotics for chickens, in: Fuller R. (Ed.), Probiotics - The scientific basis, Chapman \& Hall, London, 1992, pp. 225-257.

[9] Barrow P.A., Williams-Smith H., Tucker J.F., The effects of feeding diets containing avoparcin on the excretion of salmonellas by chickens experimentally infected with natural sources of salmonella organisms, J. Hygiene 93 (1984) 439-444.

[10] Bedford M.R., Morgan A.J., The use of enzymes in poultry diets, World's Poultry Sci. J. 52 (1996) 61-68.

[11] Bedford M.R., Patience J.F., Classen H.L., Inborr J., The effects of dietary enzyme supplementation of rye-barley-based diets on digestion and subsequent performance in weanling pigs, Can. J. Anim. Sci. 72 (1992) 97-105.

[12] Bennett C.D., Classen H.L., Riddell C., Live performance and health of broiler chickens fed diet diluted with whole or crumbled wheat, Can. J. Anim. Sci. 75 (1995) 611-614.

[13] Broz J., Schulze J., Efficacy of citric acid as a feed additive in early weaned piglets, J. Anim. Physiol. Anim. Nutr. 58 (1987) 215-223.

[14] Böhme H., Untersuchungen zur Wirksamkeit von Enzymzusätzen in der Ferkelaufzucht. Landbauforschung Völkenrode 40 (1990) 213-217.

[15] Boleman S.L., Boleman S.J., Bidner T.D., Southern L.L., Ward T.L., Pontif J.E., Pike M.M., Effect of chromium picolinate on growth, body composition, and tissue accretion in pigs, $\mathrm{J}$. Anim. Sci. 73 (1995) 2033-2042.

[16] Cherbut C., Albina E., Champ E., Dublier J.L., Cannu G., Action of guar gums on the viscosity of digestive contents and on the gastrointestinal motor function in pigs, Digestion 46 (1990) 205-213.

[17] Choct M., The role of feeding enzymes in animal nutrition towards 2000, Proc. World's Poultry Sci. Assoc., Session II-IV, XX World's Poultry Congr. New Delhi, India, 1996, pp. 125-133.

[18] Choct M., Hughes R.J., Wang J., Bedford M.R., Morgan A.J., Annison G., Increased small intestinal fermentation is partly responsible for the anti nutritive activity of non starch polysaccharides in chicken, Br. Poultry Sci. 37 (1996) 609-621.

[19] Classen H.L., Campbell G.L., Rossnagel R.G Bhatty R., Reichert D.R., Studies on the use of hulless barley in chicken diets: Deleterious effects and methods of alleviation, Can. J Amim. Sci. 65 (1985) 725-733.

[20] Conway P.L., Function and regulation of the gastrointestinal microbiota of the pig, Proc. VIth Intern. Symp. on Digestive Physiology in Pigs, Bad Doberan, 1994, pp. 232-240.

[21] Devegowda G., Herbal medicines - an untapped treasure in poultry production, Proc. World's Poultry Sci. Assoc., Session II-IV, XX World's Poultry Congr., New Dehli, India, 1996, pp. 135-140. 
[22] Dunham H.J., Edens F.W., Casas J.A., Dobrogos W.J., Efficacy of Lactobacillus reuteri for chicken and turkeys, Microbiol. Ecol. Health Dis. 7 (1994) 52-53.

[23] Eckel B., Kirchgessner M., Roth F.X., Zum Einfluss von Ameisensäure auf tägliche Zunahmen, Futteraufnahme, Futterverwertung und Verdaulichkeit, 1: Untersuchungen zur nutritiven Wirksamkeit von organischen Säuren in der Ferkelaufzucht, J. Anim. Physiol. Anim. Nutr, 67 (1992) 93-100.

[24] Eckel B., Roth F.X., Kirchgessner M., Eidelsburger U., Zum Einfluss von Ameisensäure auf die Konzentrationen an Ammoniak und biogenen Aminen im Gastrointestinaltrakt, 4: Untersuchungen zur nutritiven Wirksamkeit von organischen Säuren in der Ferkelaufzucht, J. Anim. Physiol. Anim. Nutr. 67 (1992) 198-205.

[25] Eckel B., Roth F.X., Kirchgessner M., Eidelsburger U., Zum Einfluss von Ameisensäure auf den $\mathrm{pH}$-Wert, Trockensubstanzgehalt, Konzentration flüchtiger Fettsäuren und Milchsäure im gastrointestinalen Trakt, 3 . Untersuchungen zur nutritiven Wirksamkeit von organischen Säuren in der Ferkelaufzucht, J. Anim. Physiol. Anim. Nutr. 67 (1992) 148-156.

[26] Edfors-Lilja I., Marker traits of disease resistance in the pig. Genetic studies of immune responsiveness and the intestinal receptor for $E$. coli K88. Diss., Report No. 65, Dept. Animal Breeding \& Genetics, Swed. Univ. Agric. Sciences, Uppsala, 1985

[27] Eidelsburger U., Kirchgessner M., Roth F.X., Zum Einfluss von Fumarsäure, Salzsäure, Natriumformiat, Tylosin und Toyocerin auf tägliche Zunahmen, Futteraufnahme, Futterverwertung und Verdaulichkeit, 11: Untersuchungen zur nutritiven Wirksamkeit von organischen Säuren in der Ferkelaufzucht, J. Anim. Physiol. Anim. Nutr. 68 (1992) 82-92.

[28] Eidelsburger U., Roth F.X., Kirchgessner M., Zum Einfluss von Ameisensäure, Calciumformiat und Natriumhydrogencarbonat auf tägliche Zunahmen, Futteraufnahme, Futterverwertung und Verdaulichkeit, 7: Untersuchungen zur nutritiven Wirksamkeit von organischen Säuren in der Ferkelaufzucht, J. Anim. Physiol. Anim. Nutr. 67 (1992) 258-267.

[29] Elwinger K., Engström B., Berndtson E., Fossum B., Teglöf B., Kycklinguppfödning utan foderantibiotika. Husdjurskonf. Konferensrapport, L-fak., SLU Info, Uppsala (in Swedish), 1993, pp. 87-93.

[30] Elwinger K., Engström B., Berndtson E., Fossum O., Teglöf B., Effect of protein level and feed enzyme addition on the caecal growth of C. perfringens in broiler chickens, Proc., Word's Poultry Sci. Assoc., 9th Eur. Poultry Conf., Glasgow, 1994, pp. 423-424.

[31] Elwinger K., Svensson L., Effects of dietary protein content, litter and drinker type on ammonia emission from broiler houses, J. Agric. Enging. Res. 64 (1996) 197-208.
[32] Elwinger K., Säterby B., The use of $\beta$-glucanase in practical broiler diets containing barley or oats, Swed. J. Agric. Res. 17 ( I986) 133-140.

[33] Elwinger K., Schneitz C., Berndtson E., Fossum O., Teglöf B., Engström B., Factors affecting the incidence of necrotic enteritis, caecal carriage of $C$. perfringens and bird performance in broiler chickens, Acta Vet. Scand. 33 (1992) 369-278.

[34] Elwinger K., Teglöf B., Performance of broiler chickens as influenced by a dietary enzyme complex with and without antibiotic supplementation, Arch. Geflügelk. 55 (1991) 60-73.

[35] Elwinger K., Teglöf B., Försök med hel vete till slaktkycklingar, Fjäderfä 85 (1992) 20-21.

[36] Friend T.H., Knabe D.A.., Tanksley T.D., Behaviour and performance of pigs grouped by three different methods at weaning, J. Anim. Sci. 57 (1983) 1404-1411.

[37] Fuller R., History and development of probiotics, in: Fuller E. (Ed.), Probiotics. The scientific basis, Chapman \& Hall, London, 1992, pp. 1-8.

[38] Göransson L., The effect of very restricted feeding during late pregnancy on the production performance of sows and litters, Diss., Report No. 188, Dept. Animal Nutrition \& Management, Swedish Univ. Agric. Sciences. Uppsala, 1989.

[39] Göransson L., Lange S., Lönnroth I., Post-weaning diarrhoea: Focus on diet, Pig News Inf. 16 (1995) $89 \mathrm{~N}-91 \mathrm{~N}$.

[40] Göransson L., Martinsson K., Lange S., Lönnroth I., Feed-induced lectins in piglets, J. Vet. Med. B 40 (1993) 478-484.

[41] Graham H., Åman P., Löwgren W., Enzyme supplementation of pig diets, Buraczewska L et al. (Eds.), Proc. 4th Intern. Sem. Digestive Physiol. of the Pig, Jablonna, Poland, 1988, pp. 371-376.

[42] Grassmann E., Roth F.X., Kirchgessner M., Imtermediäre Effekte durch Einsatz von Ameisensäure, 6: Untersuchungen zur nutritiven Wirksamkeit von organischen Säuren in der Ferkelaufzucht, J. Anim. Physiol. Anim. Nutr. 67 (1992) 250-257

[43] Gustafson R.H., Beck J.R., Kohland J.D., The influence of avoparcin on the establishment of Salmonella in chickens, Zentralbl. Vet. Med. B 29 (1982) 119-122.

[44] Hesselman K., Effects of $\beta$-glucanase supplementation to barley based diets for broiler chickens, Diss., Report No. 112, Dept. Animal Nutrition \& Management, Swedish Univ. Agric. Sciences, Uppsala, 1983.

[45] Hesselman K., Elwinger K., Nilsson M., Thomke S., The effect of $\beta$-glucanase supplementation, stage of ripeness and storage treatment of barley in diets fed to broiler chickens, Poultry Sci. 60 (1981) 2664-2671. 
[46] Hesselman K., Elwinger K., Thomke S., Influence of increasing levels of $\beta$-glucanase on the productive value of barley diets for broiler chickens, Feed Sci. Technol. 7 (1982) 351-358.

[47] Höhler D., Pallauf J., Effekt einer abgestuften $\mathrm{Zn-Zufuhr}$ und Zulagen von Citronensäure zu einer Mais-Soja-Diät auf Leistungsparameter und Mineralstoffverwertung beim Ferkel, J. Anim. Physiol. Anim. Nutr. 71 (1994) 189-199.

[48] Holm A., Zinc oxide in treating E. coli diarrhoea in pigs after weaning, Compendium, Contin. Educ. for the Practising Veterinarian 18 Suppl. 28, 1996.

[49] Holmgren N., Inblandning av zinkoxid i smågrisfoder som profylax mot avvänjningsdiarré. Praktiskt inriktade grisförsök, Nr. 1, Skara, Sweden (in Swedish), 1994.

[50] Holmberg T., Wierup M., Engström B., The effect of feeding diets containing avoparcin and monensin on the occurrence of Salmonella in caecum and liver in experimentally infected chickens, Poultry Sci. 63 (1984) 1144-1 148.

[51] Humbert F., Lalande F., L'Hospitalier R., Salvat G., Bennejean G., Effect of four antibiotic additives on Salmonella contamination of chicks protected by an adult chicken flora, Avian Pathol. 20 (1991) 577-584.

[52] Inborr J., Feed enzymes. Feed Enzymes in Animal Production, Conference held at Solihull 21 Sept. 1989, organized by Forum Feeds, 1989 , $8 \mathrm{p}$.

[53] Inborr J., Supplementation of pig starter diets with carbohydrate-degrading enzymes - stability, activity and mode of action, Agric. Sci. Finland (Suppl. 2) 3 ( 1994) 1-24.

[54] Inborr J., Gastrointestinal parameters influencing performance of pigs fed enzyme-supplemented barley-based feeds, Anim. Feed Sci. Technol. 71 (1998), in press.

[55] Inborr J., Bedford M.R., Stability of feed enzymes to steam pelleting during feed processing, Anim. Feed Sci. Technol. 46 (1994) 179-196.

[56] Inborr J., Grönlund A., Stability of feed enzymes in physiological conditions assayed by in vitro methods, Agric. Sci. Finland 2 (1992) 125-132.

[57] Inborr J., Ogle B., Effect of enzyme treatment of piglet feeds on performance and post weaning diarrhoea, Swed. J. Agric. Res. 18 (1988) 129-133.

[58] Inborr J., Schmitz M., Aherne F.X., Effect of adding fibre and starch-degrading enzymes to a barley-wheat based diet on performance and nutrient digestibility in different segments of the small intestine of early weaned pigs, Anim. Feed Sci. Technol. 44 (1993) 113-127.

[59] Jamroz D., Wiliczkiewicz A., Skorupinska J., Orda J., Volker L., The effect of increased Roxazyme G supplement in the broiler fed with triticale rich mixtures, Arch. Getlügelk. 60 (1996) 165-173.
[60] Johansson E., Lönnroth I., Lange S., Jonson I., Jennische E., Lönnroth C., Molecular cloning and expression of pituitary gland protein modulating intestinal fluid secretion, J. Biol. Chem. 270 (1995) 20615-20620.

[61] Jonsson E., Conway P., Probiotics for pigs, in: Fuller R. (Ed.), Probiotics. The Scientific Basis, Chapman \& Hall, London, 1992, pp. 259-316.

[62] Kahrs D., Toyocerin, ein Weg zur Stabilisierung der Darmflora, Kraftfutter 69 (1986) 364-370.

[63] Kaldhusdal M., Epedimiological, aetiological and morphological studies on necrotic enteritis in broiler chickens, Diss., Norwegian Coll. Veterinary Medicine, Oslo, Norway, 1993.

[64] Kiiskinen T., Feeding whole grain with pelleted diets to growing broiler chickens, Agric. Food Sci. Finland 5 (1996) 167-175.

[65] Kirchgessner M., Gedek B., Wiehler S., Bott A., Eidelsburger U., Roth F.X., Zum Einfluss von Ameisensäure, Calciumformiat und Natriumhydrogencarbonat auf die Keimzahlen der Mikroflora und deren Zusammensetzung in verschiedenen Segmenten des Gastrointestinaltraktes, 10: Untersuchungen zur nutritiven Wirksamkeit von organischen Säuren in der Ferkelaufzucht, J. Anim. Physiol. Anim. Nutr. 68 (1992) 73-81.

[66] Kronseder G., Wirkung und Verträglichkeit einer kohlenhydratspaltenden Enzympräparation (Roxazyme R G) in Broilerrationen, Diss., Ludwig Maximilians Universität, München, Germany, 1993, $101 \mathrm{p}$.

[67] Lange S., Lönnroth I., Passive transfer of protection against cholera toxin in rat intestine, Microbiol. Lett. 24 (1984) 165-168.

[68] Lange S., Lönnroth I., Martinsson K., Concentrations of antisecretory factor in eggs and in chicken blood plasma, Br. Poultry Sci. 35 (1994) 615-620.

[69] Lange S., Lönnroth I., Skadhauge E., Effect of anti secretory factor in pigs, Eur. Physiol. (Pflügers Arch.) 409 ( 1987 ) 328-332.

[70] Leuchtenberg W.G., Einfluss antibiotischer Futterzusätze auf die Darmflora von Hühnerküken und auf die Persistenz von Salmonella typhimurium-Infektionen, Diss., Tierärztl. Hochschule, Hannover, Germany, 1981, 85 p.

[71] Li S., Sauer W.C., Huang S.X., Gabert V.M., Effects of beta glucanase supplementation to hulless barley or wheat soybean meal diets on the digestibilities of energy, protein, $\beta$-glucans, and amino acids in young pigs, J. Anim. Sci. 74 (1996) 1649-1656.

[72] Li S., Sauer W.C., Mosenthin R., Kerr B., Effect of $\beta$-glucanase supplementation of cereal based diets for starter pigs on the apparent digestibilities of dry matter, crude protein and energy, Anim. Feed Sci. Technol. 59 (1996) 223-231. 
[73] Lin L., Quarles C., Evaluation of Primalac concentrate on reduction of $E$. coli in mail broilers, Proc. World's Poultry Sci. Assoc. Session II-IV, XX World's Poultry Congr., New Dehli, India, 1996, pp. 147-151.

[74] Linde K., Hahn I, Vielitz E., Development of live salmonella vaccines optimally attenuated for chickens, Tierärztl. Umschau 51 (1996) 23-28.

[75] Linton A.H., Al-Chalaby Z.A.M., Hinton M.H., Natural subclinical Salmonella infection in chickens: A potential model for testing the effects of various procedures on Salmonella shedding, Vet. Rec.116 (1985) 361-364.

[76] Lönnroth I., Lange S., Purification and characterization of the antisecretory factor - a protein in the central nervous system and in the gut which inhibits intestinal hypersecretion induced by cholera toxin, Biochem. Biophys. Acta 883 (1986) 138-144.

[77] Lönnroth I., Martinsson K., Lange S., Evidence of protection against diarrhoea in suckling piglets by a hormone like protein in sow's milk, J. Vet. Med. 335 (1988) 628-635.

178] Lund A., Wallgren P., Rundgren M., Artursson K., Thomke S., Fossum C., Performance, behaviour and immune capacity of domestic pigs reared for slaughter as siblings of transported and reared in mixed groups, Acta Agric. Scand. Sect. A, Anim. Sci. 48 (1998) 103-112.

[79] Lundeheim N., Pig progeny station testing of disorders and production traits, Diss., Report No. 72, Dept. Animal Breeding \& Genetics, Swed. Univ. Agric. Sciences, Uppsala, 1986.

[80] Maxwell F.J., Stewart C.S., The microbiology of the gut and the role of probiotics, in: Varley M.A. (Ed.), The Neonatal Pig. Development and Survival, CAB International, 1995. pp. 155-186.

[81] McNabb J.M., Factors affecting the energy value of wheat for poultry, World's Poultry Sci. J. 52 (1996) 69-72.

[82] Mead G.C., Role of probiotics in controlling foodborne pathogens in poultry, Proc. World's Poultry Sci. Assoc., 10th European Symp. Poultry Nutrition, Antalya, Turkey, 1995. pp. 226-232.

[83] Miles R.D., Brown R.D., Comer C.W., Oelfke E., Influence of an enzyme and an antibiotic on broiler performance, J. Appl. Anim. Res. 9 (1996) 105-117.

[84] Miller R., Newby T.J., Stokes P.D., Hampson D., Bourne F.J., The role of antigen in the aetiology of post weaning diarrhoea, Ann. Recherche Vet. 14 (1983) 487-492.

[85] Mohan B., Kadirvel R., Natarajan A., Bhaskaran M., Effect of probiotic supplementation on growth, nitrogen utilisation and serum cholesterol in broilers, Br. Poultry Sci. 37 (1996) $395-401$.
[86] Monsan P.F., Paul F., Oligosaccharide feed addjtives, in: Wallace R.J., Chesson A. (Eds.), Biotechnology in Animal Feeds and Animal Feeding, VCH Verlagsgesellschaft mbH, Weinheim, Germany, 1995, pp. 233-245.

[87] Mosenthin R., Sauer W.C., Ahrens F., Lange C.F.M. de, Bornholdt U., Effect of dietary supplements of propionic acid, siliceous earth or a combination of these on the energy, protein and amino acid digestibilities and concentrations of microbial metabolites in the digestive tract of growing pigs, Anim. Feed Sci. Techn. 37 (1992) 245-255.

[88] Newman C.W., Eslick R.F., El-Negoumy A.M., Bacterial diastase effect on the feed value of two hulless barleys for pigs, Nutr. Rep. Int. 28 (1983) 139-146.

[89] Nguyen T.H., Eckenfelder B., Levesque A., Growth promoting efficiency of two probiotics. Toyocerin ${ }^{\circledR}$ and Paciflor ${ }^{(1)}$, in broiler diets, Arch. Geflügelk. 52 (1988) 240-245.

[90] Persson E., Mikrobiellt fytas i foder till växande svin, Master thesis. Report No. 79, Dept. Animal Nutrition \& Management, Swed. Univ. Agric. Sciences, Uppsala, Sweden, (in Swedish), 1996. $39 \mathrm{p}$.

[91] Petersen V.E., Anti-nutritive stoffer i rapsfrø og deres indflydelse på slagtekyllinger, Dansk Erhvervsfjerkræ 11 (1991) 243-245 (in Danish).

[92] Petersen V.E., Fodervardi af arter og rapsfrø til slagtekyllinger. Statens Husdyrbrugsfor $\varnothing \mathrm{g}$, Medd. 801, Copenhagen, (in Danish), 1991.

[93] Pettersson D., Combining proteases and fibre degrading enzymes, Feed Int. 17 (1996) 59-65.

[94] Pettersson D., Åman P., Effects of enzyme supplementation of diets based on wheat, rye or triticale on their productive value for broiler chickens, Feed Sci. Technol. 20 (1988) 313-324.

[95] Pollman D.S., Probiotics in pig diets, in: Haresign W., Cole D.J.A. (Eds.), Recent Advances in Animal Nutrition, Butterworths, London, 1986. pp. 193-205.

[96] Poppe C., McFadden K.A., Demczuk W.H.B. Drug resistance, plasmids, biotypes and susceptibility to bacteriophages of Salmonella isolated from poultry in Canada, Int. J. Food Microbiol. 30 (1996) 325-344.

1971 Pusztai A., Grant G., King T.P., Clarke E.M.W., Chemical probiosis, in: Haresign W., Colc D.J.A. (Eds.), Recent Advances in Animal Nutrition, Butterworths, London, 1990, pp. 47-60.

[98] Ratcliffe B., Cole C.B., Fuller R., Newport M.J., The effect of yoghurt and milk fermented with a porcine intestinal strain of Lactobacillus reuteri on the performance and gastrointestinal flora of pigs weaned at two days of age, Food Microbiol. 3 (1986) 203-211.

[99] Reiter B., The lactoperoxidase system in bovine milk, in: Pruitt K.M., Tenovuo J.O. (Eds.), The lactoperoxidase system, Marcel Dekker Inc., New York, 1985, pp. 123-141. 
[100] Roth F.X., Eckel B., Kirchgessner M., Eidelsburger U., Zum Einfluss der Ameisensäure auf $\mathrm{pH}$-Wert, Trockenmassegehalt, Konzentrationen an flüchtigen Fettsäuren und Milchsäure im Gastrointestinaltrakt, 3: Untersuchungen zur nutritiven Wirksamkeit von organischen Säuren in der Ferkelaufzucht, J. Anim. Physiol. Anim. Nutr. 67 (1992) 148-156.

[101] Roth F.X., Eidelsburger U., Kirchgessner M., Zum Einfluss von Fumarsäure, Salzsäure, Natriumformiat, Tylosin und Toyocerin auf $\mathrm{pH}$ Wert, Trockenmassegehalt, Konzentration an Carbonsäuren und Ammoniak in verschiedenen Segmenten des Gastrointestinaltraktes, 12: Unterzuchungen zur nutritiven Wirksamkeit von organischen Säuren in der Ferkelaufzucht, J. Anim. Physiol. Anim. Nutr. 68 (1992) 93-103.

[102] Rundgren M., Löfquist I., Effects on performance and behaviour of mixing $20 \mathrm{~kg}$ pigs fed individually, Anim. Prod. 49 (1989) 311-315.

[103] Sigfridson K., Lange S., Lönnroth I., Anti-secretory protein and feed induced lectines in sow and suckling piglet, Abstract, 46th Ann. Meeting EAAP, Prague, Czech Republic, 1995.

[104] Slominski B.A., Campbell L.D., Guenter W., Enhancement of the feeding value of low-glucosinolate rapeseed by the supplementation of poultry diets with exogenous enzymes, Proc. 19th World's Poultry Congress, Amsterdam, Netherlands, Vol. 2, 1992, pp. 241-245.

[105] Stanley V.G., Chukwu H., Gray C., Thompson D., Effects of lactose and Bio-Mos in dietary application on growth and total coliform bacteria reduction in broiler chicks, Proc. Poultry Sci. Assoc. 85th Ann. Meeting, Lousville, Kentucky, 75, Suppl. 1, 1996.

[106] Stewart C.S., Chesson A., Making sense of probiotics, Pig Vet. J. 31 (1993) 11-33.

[107] Stigson M., Grisningsbeteende och smågrisdödlighet, Swed. Univ. Agric. Sciences, Research Information Centre, Rapporter, Allmänt 17, Uppsala, Sweden, (in Swedish), 1979
[108] Thacker P.A., Campbell G.L., Grootwassink J.W.D., The effect of enzyme supplementation on the nutritive value of rye-based diets for swine, Can. J. Anim. Sci. 71 (1991) 489-496.

[109] Thacker P.A., Campbell G.L., Grootwassink J.W.D., Effects of salinomycin and enzyme supplementation on nutrient digestibility and the performance of pigs fed barley- or rye-based diets, Can. J. Anim. Sci. 72 (1992) 117-125.

[110] Thomke S., On the influence of different stages of ripeness on the productive value of barley fed to chickens, laying hens, rats and mice, Acta Agric. Scand. 22 (1972) 107-120.

[111] Thomke S., Rundgren M., Hesselman K., The effect of feeding high-viscosity barley to pigs, Proc. 3Ist Ann. Meet. EAAP, München, Comm. Animal Nutrition, $1980,5 \mathrm{p}$.

[112] Tuschy D., Verwendung von Probiotika als Leistungsförderer in der Tierernährung, Übers. Tierern. 14 (1986) 157-178.

[113] Vranjes V., Spring M.P., Pfirter H.P., Trichoderma viride enzyme complex as affected by extrusion of barley based broiler diets: response, Arch. Geflügelk. 60 (1996) 81-87.

[114] Vranjes M.V., Wenk C., Influence of Trichoderma viride enzyme complex on nutrient utilization and performance of laying hens in diets with and without antibiotic supplementation, Poultry Sci. 75 (1996) 551-555.

[115] Wantia D., Einige Gesichtspunkte zur Wirkung kohlenhydrat-spaltender Futterzusatzenzyme in roggenhaltigen Rationen beim Geflügel, Diss., Ludwig-Maximilians-Universität, München, Germany, 1993, 68 p.

[116] Yalda A.Y., Forbes J.M., Effects of food intake, soaking time, enzyme and cornflour addition on the digestibility of the diet and performance of broilers given wet food, $\mathrm{Br}$. Poultry Sci. 37 (1996) 797-807. 